\title{
An Internal Control Evaluation Tool For The Construction Industry
}

Lou X. Orchard, Clayton State University, USA

Scott L. Butterfield, Clayton State University, USA

\begin{abstract}
This paper presents a Control Objectives Reconciliation, a tool that independent auditors of clients in the construction industry should find useful in performing a preliminary evaluation of the client's internal control system. Auditors are advised to compare their client's control objectives with those presented in Exhibits 1 through 7. Where the client's system appears to omit significant control objectives, the auditor should consider the risks brought on or magnified by the omission during the preliminary evaluation of the client's internal control system. The Control Objectives Reconciliation is also potentially useful to Construction Company CFOs or Controllers who may be concerned about the adequacy of their company's internal control system. The Reconciliation also highlights for Construction Company CFOs or Controllers those internal controls deemed to be important to their external, independent auditors.
\end{abstract}

Keywords: Construction, Independent Audit, Internal Control Objectives

\section{INTRODUCTION}

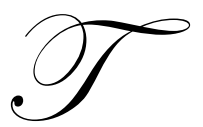

his paper presents a tool that many independent auditors will find useful in performing a preliminary assessment of the appropriateness and completeness of the design of the internal control system of a client in the construction industry. This tool, called the Control Objectives Reconciliation (CO Reconciliation), is potentially useful to auditors of both publicly-traded and privately-held construction companies, as well as to controllers or CFOs of construction companies who may have concerns about the quality of their company's internal control system. The CO Reconciliation is important and timely because of current economic conditions as well as recent changes in auditing standards issued by the Public Company Accounting Oversight Board (PCAOB).

\section{Effects of the Economy}

Construction companies have been hit especially hard in the recent economic downturn, which began in December 2007 and continues as of this writing. The current recession has driven many companies (including construction firms) into bankruptcy and has weakened countless others. The recession may lead an independent auditor to increase his or her assessment of inherent risk for at least some financial statement accounts and assertions. All other things being held equal, this increase in assessed risk would indicate a need for more effective substantive testing of those accounts and assertions on the part of the auditor. As a result, the nature, timing and extent of the auditor's testing would be amplified.

The nature, timing and extent of an auditor's substantive testing are also affected by his or her assessment of the client's control risk. In this economy, it is particularly important for auditors to exercise care in evaluating the internal control systems of their clients. Several recent developments have affected the auditor's study of a client's internal control system. Next, we highlight these recent changes. 


\section{Recent Regulatory Changes}

Section 404 of the Sarbanes-Oxley Act of 2002 requires management of publicly-traded companies to assess the effectiveness of their company's internal control system. It also requires the company's independent auditor to attest to (i.e., report on) this assessment by management as part of the audit engagement. The Public Company Accounting Oversight Board (PCAOB) has released guidance to auditors performing such combined engagements, in the form of two Standards. The first is PCAOB Auditing Standard No. 2, "An Audit of Internal Control Over Financial Reporting Performed in Conjunction With An Audit of Financial Statements" (Standard No. 2, issued in March 2004). The second, which superseded Standard No. 2, is PCAOB Auditing Standard No. 5, "An Audit of Internal Control Over Financial Reporting That Is Integrated with An Audit of Financial Statements" (Standard No. 5, issued in June 2007). The CO Reconciliation tool presented in this paper, while intended to apply in the context of such a combined or integrated audit engagement under PCAOB standards, may nevertheless be useful in performing various other kinds of audit engagements as well. The CO Reconciliation tool is consistent with PCAOB Standard No. 5.

\section{THE CONTROL OBJECTIVES RECONCILIATION}

Exhibits 1 through 7 present the CO Reconciliation tool according to the significant business cycles for the construction industry.

The significant business cycles highlighted for the construction industry include:

- $\quad$ The Expenditure Cycle (outlined in Exhibit 1)

- $\quad$ The Fixed Assets Cycle (outlined in Exhibit 2)

- $\quad$ The Inventory Management Cycle (outlined in Exhibit 3)

- $\quad$ The Payroll and Personnel Cycle (outlined in Exhibit 4)

- $\quad$ The Billings Cycle (outlined in Exhibit 5)

- $\quad$ The Treasury Cycle (outlined in Exhibit 6)

- $\quad$ The Estimating, Job Cost and Revenue Recognition Cycle (outlined in Exhibit 7).

The first column specifies, for each business cycle, the principal business activities of that business cycle. The second column provides, for each of these activities, a number of internal control objectives. Auditors are advised, for each cycle and activity, to compare the control objectives of the client's control system with those shown in Exhibits 1-7. This comparison helps ensure that no important control objectives have been omitted from the client's system - and, in cases where one or more have been omitted, serves as a reminder to the auditor to consider the potential negative effects of such an omission on the auditor's preliminary assessment of the design of the client's control system. The third column lists the accounts affected by the control objective, as well as (in parentheses) the assertions the auditor will be primarily concerned with (for each of those accounts) that would be addressed by that control objective. ${ }^{1}$

The control objectives shown in Exhibits 1-7 are not intended to be all-inclusive, because each client and each engagement is unique. For example, client management may have identified additional risks for which they believe additional control objectives are necessary. Given the unique circumstances of the engagement, the auditor may do the same. Although beyond the scope of this paper, an important subsequent step for the auditor to take would be to consider which control activities would be necessary in order to provide assurance that each control objective is being met.

\footnotetext{
1 The assertions listed by abbreviation in parentheses in column 3 of Exhibits 1 through 7 are derived from, and in some cases identical to, the assertions listed in AICPA auditing standards (AU) Section 326, paragraph 15 and discussed in AU Section 326 paragraphs 14 through 19, Codification of Statements on Auditing Standards, online.
} 


\section{Exhibit 1: Control Objectives Reconciliation for the Expenditure Cycle}

\begin{tabular}{|c|c|c|}
\hline $\begin{array}{l}\text { Principal Business } \\
\text { Activity }\end{array}$ & Control Objective & $\begin{array}{l}\text { Accounts Affected (Auditor Assertion Addressed by that } \\
\text { Control Objective*) }\end{array}$ \\
\hline Purchasing & Purchase orders are placed only for approved requisitions. & $\begin{array}{l}\text { Operating Expenses }\left(\mathrm{V}^{*}\right) \text {, Payables }(\mathrm{V}) \\
\text { Accrued Expenses }(\mathrm{V}) \text {, Prepaid Expenses }(\mathrm{V})\end{array}$ \\
\hline Purchasing & Purchase orders are entered accurately. & $\begin{array}{l}\text { Operating Expenses (R), Payables (R), } \\
\text { Accrued Expenses (R), Prepaid Expenses (R) }\end{array}$ \\
\hline $\begin{array}{c}\text { Pur- } \\
\text { chasing }\end{array}$ & All purchase orders issued are input and processed. & $\begin{array}{l}\text { Operating Expenses (Co), Payables (Co), } \\
\text { Accrued Expenses (Co), Prepaid Expenses (Co) }\end{array}$ \\
\hline $\begin{array}{c}\text { Processing } \\
\text { Accounts Payable (A/P) }\end{array}$ & Amounts posted to accounts payable represent goods received. & $\begin{array}{l}\text { Operating Expenses (V), Payables (V), } \\
\text { Accrued Expenses (V), Prepaid Expenses (V) }\end{array}$ \\
\hline $\begin{array}{l}\text { Processing } \\
\mathrm{A} / \mathrm{P}\end{array}$ & Amounts posted to accounts payable represent services received. & $\begin{array}{l}\text { Operating Expenses (V), Payables (V), } \\
\text { Accrued Expenses (V), Prepaid Expenses (V) }\end{array}$ \\
\hline $\begin{array}{c}\text { Processing } \\
\mathrm{A} / \mathrm{P}\end{array}$ & Accounts payable amounts are accurately calculated and recorded. & $\begin{array}{l}\text { Operating Expenses (R), Payables (R), } \\
\text { Accrued Expenses (R), Prepaid Expenses (R) }\end{array}$ \\
\hline $\begin{array}{l}\text { Processing } \\
\mathrm{A} / \mathrm{P}\end{array}$ & All amounts for goods received are input and processed to accounts payable. & $\begin{array}{l}\text { Operating Expenses (C), Payables (C), } \\
\text { Accrued Expenses (C), Prepaid Expenses (C) }\end{array}$ \\
\hline $\begin{array}{l}\text { Processing } \\
\text { A/P }\end{array}$ & All amounts for services received are input and processed to accounts payable & $\begin{array}{l}\text { Operating Expenses (C), Payables (C), } \\
\text { Accrued Expenses (C), Prepaid Expenses (C) }\end{array}$ \\
\hline $\begin{array}{c}\text { Processing } \\
\mathrm{A} / \mathrm{P}\end{array}$ & Amounts for goods or services received are recorded in the appropriate period. & $\begin{array}{l}\text { Operating Expenses }(\mathrm{Cu}) \text {, Payables }(\mathrm{Cu}), \\
\text { Accrued Expenses }(\mathrm{Cu}) \text {, Prepaid Expenses }(\mathrm{Cu})\end{array}$ \\
\hline $\begin{array}{l}\text { Processing } \\
\mathrm{A} / \mathrm{P}\end{array}$ & Accounts payable are only adjusted for valid reasons. & $\begin{array}{l}\text { Operating Expenses }(\mathrm{Co}, \mathrm{V}) \text {, Payables }(\mathrm{Co}, \mathrm{V}), \text { Accrued } \\
\text { Expenses }(\mathrm{Co}, \mathrm{V}) \text {, Prepaid Expenses }(\mathrm{Co}, \mathrm{V})\end{array}$ \\
\hline $\begin{array}{l}\text { Processing } \\
\text { A/P }\end{array}$ & Credit notes and other adjustments are accurately calculated and recorded. & $\begin{array}{l}\text { Operating Expenses (R), Payables (R), } \\
\text { Accrued Expenses (R), Prepaid Expenses (R) }\end{array}$ \\
\hline $\begin{array}{c}\text { Processing } \\
\mathrm{A} / \mathrm{P}\end{array}$ & $\begin{array}{l}\text { All valid credit notes and other adjustments related to accounts payable are } \\
\text { input and processed. }\end{array}$ & $\begin{array}{l}\text { Operating Expenses }(\mathrm{Co}, \mathrm{V}), \text { Payables }(\mathrm{Co}, \mathrm{V}), \text { Accrued } \\
\text { Expenses }(\mathrm{Co}, \mathrm{V}) \text {, Prepaid Expenses }(\mathrm{Co}, \mathrm{V})\end{array}$ \\
\hline $\begin{array}{c}\text { Processing } \\
\mathrm{A} / \mathrm{P}\end{array}$ & Credit notes and other adjustments are recorded in the appropriate period. & $\begin{array}{l}\text { Operating Expenses }(\mathrm{Cu}) \text {, Payables }(\mathrm{Cu}), \\
\text { Accrued Expenses }(\mathrm{Cu}) \text {, Prepaid Expenses }(\mathrm{Cu})\end{array}$ \\
\hline $\begin{array}{l}\text { Processing } \\
\text { A/P }\end{array}$ & $\begin{array}{l}\text { Assets and liabilities reflect the existing business circumstances and economic } \\
\text { conditions in accordance with the accounting policies being used. }\end{array}$ & Payables (\$), Accrued Expenses (\$), Prepaid Expenses (\$) \\
\hline
\end{tabular}

*Assertion abbreviations: $\mathbf{C o}=$ Completeness; $\mathbf{C u}=$ Cutoff; $\mathbf{P}=$ Presentation; $\mathbf{R}=$ Recording; $\mathbf{V}=$ Validity; $\$=$ Valuation. 


\section{Exhibit 1: Control Objectives Reconciliation for the Expenditure Cycle (continued)}

\begin{tabular}{|c|c|c|}
\hline $\begin{array}{l}\text { Principal Business } \\
\text { Activity }\end{array}$ & Control Objective & $\begin{array}{l}\text { Accounts Affected (Auditor Assertion Addressed by that Control } \\
\text { Objective*) }\end{array}$ \\
\hline $\begin{array}{l}\text { Processing } \\
\text { A/P }\end{array}$ & $\begin{array}{l}\text { Financial information is not presented in a misleading way, and all } \\
\text { information that is necessary for fair presentation and compliance with } \\
\text { professional standards or legal requirements is disclosed. }\end{array}$ & $\begin{array}{l}\text { Operating Expenses }(\mathrm{P}) \text {, Payables }(\mathrm{P}) \text {, Accrued Expenses }(\mathrm{P}) \text {, Prepaid } \\
\text { Expenses }(\mathrm{P})\end{array}$ \\
\hline $\begin{array}{c}\text { Processing } \\
\text { Disbursements }\end{array}$ & Disbursements are only made for goods and services received. & $\begin{array}{l}\text { Operating Expenses (V), Payables (Co), } \\
\text { Accrued Expenses (Co), Prepaid Expenses (V) }\end{array}$ \\
\hline $\begin{array}{c}\text { Processing } \\
\text { Disbursements }\end{array}$ & Disbursements are distributed to the appropriate suppliers. & Payables (Co), Accrued Expenses (Co), Prepaid Expenses (V) \\
\hline $\begin{array}{c}\text { Processing } \\
\text { Disbursements }\end{array}$ & Disbursements are accurately calculated and recorded. & $\begin{array}{l}\text { Operating Expenses (R), Payables (R), } \\
\text { Accrued Expenses (R), Prepaid Expenses (R) }\end{array}$ \\
\hline $\begin{array}{c}\text { Processing } \\
\text { Disbursements }\end{array}$ & All disbursements are recorded & $\begin{array}{l}\text { Operating Expenses (Co), Payables (V), } \\
\text { Accrued Expenses (V), Prepaid Expenses (Co) }\end{array}$ \\
\hline $\begin{array}{c}\text { Processing } \\
\text { Disbursements }\end{array}$ & Disbursements are recorded in the period in which they are issued. & $\begin{array}{l}\text { Operating Expenses }(\mathrm{Cu}) \text {, Payables }(\mathrm{Cu}), \\
\text { Accrued Expenses }(\mathrm{Cu}) \text {, Prepaid Expenses }(\mathrm{Cu})\end{array}$ \\
\hline $\begin{array}{c}\text { Maintaining Supplier } \\
\text { Master File }\end{array}$ & Only valid changes are made to the supplier master file. & $\begin{array}{l}\text { Operating Expenses }(\mathrm{Co}, \mathrm{V}) \text {, Payables }(\mathrm{Co}, \mathrm{V}), \\
\text { Accrued Expenses }(\mathrm{Co}, \mathrm{V}) \text {, Prepaid Expenses }(\mathrm{Co}, \mathrm{V})\end{array}$ \\
\hline $\begin{array}{l}\text { Maintaining Supplier } \\
\text { Master File } \\
\end{array}$ & All valid changes to the supplier master file are input and processed. & $\begin{array}{l}\text { Operating Expenses }(\mathrm{Co}, \mathrm{V}) \text {, Payables }(\mathrm{Co}, \mathrm{V}), \\
\text { Accrued Expenses }(\mathrm{Co}, \mathrm{V}) \text {, Prepaid Expenses }(\mathrm{Co}, \mathrm{V})\end{array}$ \\
\hline $\begin{array}{l}\text { Maintaining Supplier } \\
\text { Master File }\end{array}$ & Changes to the supplier master file are accurate. & $\begin{array}{l}\text { Operating Expenses (R), Payables (R), } \\
\text { Accrued Expenses (R), Prepaid Expenses (R) }\end{array}$ \\
\hline $\begin{array}{l}\text { Maintaining Supplier } \\
\text { Master File }\end{array}$ & Changes to the supplier master file are processed in a timely manner & $\begin{array}{l}\text { Operating Expenses }(\mathrm{Co}, \mathrm{V}), \text { Payables }(\mathrm{Co}, \mathrm{V}), \\
\text { Accrued Expenses }(\mathrm{Co}, \mathrm{V}) \text {, Prepaid Expenses }(\mathrm{Co}, \mathrm{V})\end{array}$ \\
\hline $\begin{array}{l}\text { Maintaining Supplier } \\
\text { Master File }\end{array}$ & Supplier master file data remains pertinent. & $\begin{array}{l}\text { Operating Expenses }(\mathrm{Co}, \mathrm{V}), \text { Payables }(\mathrm{Co}, \mathrm{V}), \\
\text { Accrued Expenses }(\mathrm{Co}, \mathrm{V}) \text {, Prepaid Expenses }(\mathrm{Co}, \mathrm{V})\end{array}$ \\
\hline
\end{tabular}

*Assertion abbreviations: $\mathbf{C o}=$ Completeness; $\mathbf{C u}=$ Cutoff; $\mathbf{P}=$ Presentation; $\mathbf{R}=$ Recording; $\mathbf{V}=$ Validity; $\$=$ Valuation. 


\section{Exhibit 2: Control Objectives Reconciliation for the Fixed Assets Cycle}

\begin{tabular}{|c|c|c|}
\hline $\begin{array}{l}\text { Principal Business } \\
\text { Activity }\end{array}$ & Control Objective & $\begin{array}{c}\text { Accounts Affected (Auditor Assertion Addressed by } \\
\text { that Control Objective*) }\end{array}$ \\
\hline Acquiring Fixed Assets & Recorded fixed asset acquisitions represent fixed assets acquired by the organization. & Property (V) \\
\hline Acquiring Fixed Assets & Fixed asset acquisitions are accurately recorded. & Property $(\mathrm{R})$ \\
\hline Acquiring Fixed Assets & Fixed asset acquisitions are recorded in the appropriate period & Property $(\mathrm{Cu})$ \\
\hline Acquiring Fixed Assets & All fixed asset acquisitions are recorded. & Property $(\mathrm{Co})$ \\
\hline Depreciating Fixed Assets & Depreciation charges are valid. & Property (Co), Depreciation Expense (V) \\
\hline Depreciating Fixed Assets & Depreciation charges are accurately calculated and recorded & Property (R), Depreciation Expense (R) \\
\hline Depreciating Fixed Assets & All depreciation charges are recorded in the appropriate period. & Property $(\mathrm{V}, \mathrm{Cu})$, Depreciation Expense $(\mathrm{Co}, \mathrm{Cu})$ \\
\hline Disposing of Fixed Assets & Recorded fixed asset disposals represent actual disposals. & Property $(\mathrm{Co})$ \\
\hline Disposing of Fixed Assets & All fixed asset disposals are recorded. & Property (V) \\
\hline Disposing of Fixed Assets & Fixed asset disposals are accurately calculated and recorded. & Property (R) \\
\hline Disposing of Fixed Assets & Fixed asset disposals are recorded in the appropriate period. & Property $(\mathrm{Cu})$ \\
\hline Disposing of Fixed Assets & $\begin{array}{l}\text { Fixed assets to be disposed of (under sales contract or as identified by management } \\
\text { for sale) are communicated to accounting and financial reporting for compliance with } \\
\text { professional standards and fair presentation. }\end{array}$ & Property $(\$, P)$ \\
\hline Managing Fixed Assets & Records of fixed asset maintenance activity are accurately maintained. & Property $(\mathrm{Co})$ \\
\hline Managing Fixed Assets & Fixed assets are adequately safeguarded. & Property (V) \\
\hline Managing Fixed Assets & Fixed asset maintenance records are updated in a timely manner. & Property (Co) \\
\hline Managing Fixed Assets & $\begin{array}{l}\text { Fixed assets reflect the existing business circumstances and economic conditions in } \\
\text { accordance with the accounting policies being used. }\end{array}$ & Property $(\$)$ \\
\hline Managing Fixed Assets & $\begin{array}{l}\text { Financial information is appropriately presented and all information that is necessary } \\
\text { for fair presentation and compliance with professional standards or legal } \\
\text { requirements is disclosed. }\end{array}$ & $\begin{array}{l}\text { Property }(\mathrm{P}) \\
\text { Depreciation Expense }(\mathrm{P})\end{array}$ \\
\hline $\begin{array}{l}\text { Maintaining Fixed Asset } \\
\text { Register and/ or Master } \\
\text { File } \\
\end{array}$ & Only valid changes are made to the fixed asset register and/or master file. & Property $(\mathrm{Co}, \mathrm{V})$ \\
\hline $\begin{array}{c}\text { Maintaining Fixed Asset } \\
\text { Register and/ or Master File }\end{array}$ & $\begin{array}{l}\text { All valid changes to the fixed asset register and/or master file are input and } \\
\text { processed. }\end{array}$ & $\begin{array}{l}\text { Property }(\mathrm{Co}, \mathrm{V}), \\
\text { Depreciation Expense }(\mathrm{Co}, \mathrm{V})\end{array}$ \\
\hline $\begin{array}{c}\text { Maintaining Fixed Asset } \\
\text { Register and/ or Master File }\end{array}$ & Changes to the fixed asset register and/or master file are accurate. & $\begin{array}{l}\text { Property }(\mathrm{R}), \\
\text { Depreciation Expense (R) }\end{array}$ \\
\hline $\begin{array}{c}\text { Maintaining Fixed Asset } \\
\text { Register and/ or Master File }\end{array}$ & $\begin{array}{l}\text { Changes to the fixed asset register and/or master file are processed in a timely } \\
\text { manner. }\end{array}$ & $\begin{array}{l}\text { Property }(\mathrm{Co}, \mathrm{V}) \\
\text { Depreciation Expense }(\mathrm{Co}, \mathrm{V})\end{array}$ \\
\hline $\begin{array}{l}\text { Maintaining Fixed Asset } \\
\text { Register and/ or Master File }\end{array}$ & Fixed asset register and/or master file data remains pertinent. & $\begin{array}{l}\text { Property }(\mathrm{Co}, \mathrm{V}) \\
\text { Depreciation Expense }(\mathrm{Co}, \mathrm{V})\end{array}$ \\
\hline
\end{tabular}

*Assertion abbreviations: $\mathbf{C o}=$ Completeness; $\mathbf{C u}=$ Cutoff; $\mathbf{P}=$ Presentation $\mathbf{R}=$ Recording; $\mathbf{V}=$ Validity; $\$=$ Valuation. 
Exhibit 3: Control Objectives Reconciliation for the Inventory Management Cycle

\begin{tabular}{|c|c|c|}
\hline $\begin{array}{l}\text { Principal Business } \\
\text { Activity }\end{array}$ & Control Objective & $\begin{array}{l}\text { Accounts Affected (Auditor Assertion Addressed by that Control } \\
\text { Objective*) }\end{array}$ \\
\hline Managing Inventory & Inventory is salable or usable. & Inventory (\$), Cost of Sales $(\$)$ \\
\hline Managing Inventory & Inventory is adequately safeguarded. & Inventory (V), Cost of Sales (V) \\
\hline Managing Inventory & $\begin{array}{l}\text { Adjustments to inventory prices or quantities relate to valid price changes } \\
\text { and physical inventory differences. }\end{array}$ & $\begin{array}{l}\text { Inventory }(\mathrm{V}, \mathrm{Co}, \mathrm{R}) \\
\text { Cost of Sales }(\mathrm{V}, \mathrm{Co}, \mathrm{R})\end{array}$ \\
\hline Managing Inventory & All adjustments to inventory prices or quantities are recorded. & $\begin{array}{l}\text { Inventory }(\mathrm{V}, \mathrm{Co}, \mathrm{R}) \\
\text { Cost of Sales }(\mathrm{V}, \mathrm{Co}, \mathrm{R})\end{array}$ \\
\hline Managing Inventory & $\begin{array}{l}\text { Adjustments to inventory prices or quantities are recorded in a timely } \\
\text { manner and in the appropriate period. }\end{array}$ & $\begin{array}{l}\text { Inventory }(\mathrm{Cu}) \\
\text { Cost of Sales }(\mathrm{Cu})\end{array}$ \\
\hline Managing Inventory & Adjustments to inventory prices or quantities are recorded accurately. & Inventory (R), Cost of Sales (R) \\
\hline Managing Inventory & $\begin{array}{l}\text { Inventory reflects the existing business circumstances and economic } \\
\text { conditions in accordance with the accounting policies being used. }\end{array}$ & Inventory (\$) \\
\hline Managing Inventory & $\begin{array}{l}\text { Financial information is appropriately presented, and all information that is } \\
\text { necessary for fair presentation and compliance with professional standards } \\
\text { or legal requirements is disclosed. }\end{array}$ & Inventory $(\mathrm{P})$ \\
\hline $\begin{array}{l}\text { Receiving And Storing } \\
\text { Raw Materials }\end{array}$ & $\begin{array}{l}\text { Raw materials are received and accepted only if they have valid purchase } \\
\text { orders. }\end{array}$ & Inventory (V) \\
\hline $\begin{array}{l}\text { Receiving And Storing } \\
\text { Raw Materials }\end{array}$ & Raw materials received are recorded accurately. & Inventory (R), Cost of Sales (R) \\
\hline $\begin{array}{l}\text { Receiving And Storing } \\
\text { Raw Materials }\end{array}$ & All raw materials received are recorded. & Inventory (Co), Cost of Sales (Co) \\
\hline $\begin{array}{l}\text { Receiving And Storing } \\
\text { Raw Materials }\end{array}$ & $\begin{array}{l}\text { Receipts of raw materials are recorded in a timely manner and in the } \\
\text { appropriate period. }\end{array}$ & Inventory $(\mathrm{Cu})$, Cost of Sales $(\mathrm{Cu})$ \\
\hline
\end{tabular}

*Assertion abbreviations: $\mathbf{C o}=$ Completeness; $\mathbf{C u}=$ Cutoff; $\mathbf{P}=$ Presentation; $\mathbf{R}=$ Recording; $\mathbf{V}=$ Validity; $\mathbf{\$}=$ Valuation. 
Exhibit 3: Control Objectives Reconciliation for the Inventory Management Cycle (continued)

\begin{tabular}{|c|c|c|}
\hline $\begin{array}{l}\text { Principal Business } \\
\text { Activity }\end{array}$ & Control Objective & $\begin{array}{c}\text { Accounts Affected (Auditor Assertion Addressed by that Control } \\
\text { Objective*) }\end{array}$ \\
\hline $\begin{array}{l}\text { Receiving And Storing } \\
\text { Raw Materials }\end{array}$ & Defective raw materials are returned in a timely manner to suppliers. & Inventory (V), Cost of Sales (V) \\
\hline $\begin{array}{l}\text { Requisitioning } \\
\text { Materials }\end{array}$ & $\begin{array}{l}\text { All transfers of raw materials to production are recorded accurately and in } \\
\text { the appropriate period. }\end{array}$ & Inventory $(\mathrm{R}, \mathrm{Cu})$, Cost of Sales $(\mathrm{R}, \mathrm{Cu})$ \\
\hline Producing Inventory & $\begin{array}{l}\text { All raw materials consumed are recorded in sufficient detail to be identified } \\
\text { with applicable classifications, such as job orders or allocation to units in } \\
\text { process. }\end{array}$ & Inventory (R), Cost of Sales (R) \\
\hline Producing Inventory & $\begin{array}{l}\text { Direct and indirect labor costs posted to inventory accounts are consistent } \\
\text { with payroll time and attendance data. }\end{array}$ & Inventory (R), Cost of Sales (R) \\
\hline Producing Inventory & $\begin{array}{l}\text { All direct and indirect labor costs are recorded in sufficient detail to be } \\
\text { identified with applicable classifications, such as job orders or allocation to } \\
\text { units in process. }\end{array}$ & Inventory (R), Cost of Sales (R) \\
\hline Producing Inventory & $\begin{array}{l}\text { Overhead rates are consistent with actual overhead expenses and plant } \\
\text { capacity }\end{array}$ & Inventory (R), Cost of Sales (R) \\
\hline Producing Inventory & Overhead is applied to production based on established overhead rates. & Inventory (R), Cost of Sales (R) \\
\hline Producing Inventory & $\begin{array}{l}\text { Standard costs are consistent with actual direct expenses and plant capacity. } \\
\text { [Note: Applies to STANDARD COSTING SYSTEMS ONLY] }\end{array}$ & Inventory (R), Cost of Sales (R) \\
\hline Producing Inventory & $\begin{array}{l}\text { Finished goods inventory costing is accurately calculated and recorded } \\
\text { using established standards. [Note: Applies to STANDARD COSTING } \\
\text { SYSTEMS ONLY] }\end{array}$ & Inventory (R), Cost of Sales (R) \\
\hline Producing Inventory & $\begin{array}{l}\text { All transfers of completed units of production to fixed goods inventory are } \\
\text { recorded completely and accurately in the appropriate period. }\end{array}$ & $\begin{array}{l}\text { Inventory }(\mathrm{R}, \mathrm{Co}, \mathrm{Cu}) \\
\text { Cost of Sales }(\mathrm{R}, \mathrm{Co}, \mathrm{Cu})\end{array}$ \\
\hline Producing Inventory & $\begin{array}{l}\text { All defective products and scrap resulting from the production process are } \\
\text { recorded completely and accurately in the appropriate period. }\end{array}$ & $\begin{array}{l}\text { Inventory }(\mathrm{R}, \mathrm{Co}, \mathrm{Cu}) \\
\text { Cost of Sales }(\mathrm{R}, \mathrm{Co}, \mathrm{Cu})\end{array}$ \\
\hline $\begin{array}{l}\text { Handling Finished } \\
\text { Products }\end{array}$ & $\begin{array}{l}\text { Finished goods returned by customers are recorded completely and } \\
\text { accurately in the appropriate period. }\end{array}$ & $\begin{array}{l}\text { Inventory }(\mathrm{R}, \mathrm{Co}, \mathrm{Cu}) \\
\text { Cost of Sales }(\mathrm{R}, \mathrm{Co}, \mathrm{Cu})\end{array}$ \\
\hline
\end{tabular}

*Assertion abbreviations: $\mathbf{C o}=$ Completeness; $\mathbf{C u}=$ Cutoff; $\mathbf{P}=$ Presentation; $\mathbf{R}=$ Recording; $\mathbf{V}=$ Validity; $\$=$ Valuation. 
Exhibit 3: Control Objectives Reconciliation for the Inventory Management Cycle (continued)

\begin{tabular}{|c|c|c|}
\hline $\begin{array}{l}\text { Principal } \\
\text { Business } \\
\text { Activity }\end{array}$ & Control Objective & $\begin{array}{c}\text { Accounts Affected (Auditor Assertion Addressed by that Control } \\
\text { Objective*) }\end{array}$ \\
\hline $\begin{array}{l}\text { Handling Finished } \\
\text { Products }\end{array}$ & $\begin{array}{l}\text { Finished goods received from production are recorded completely and } \\
\text { accurately in the appropriate period. }\end{array}$ & $\begin{array}{l}\text { Inventory }(\mathrm{R}, \mathrm{Co}, \mathrm{Cu}) \\
\text { Cost of Sales }(\mathrm{R}, \mathrm{Co}, \mathrm{Cu})\end{array}$ \\
\hline $\begin{array}{l}\text { Handling Finished } \\
\text { Products }\end{array}$ & $\begin{array}{l}\text { Goods received from production or returned by customers are only } \\
\text { accepted in accordance with the organization's policies. }\end{array}$ & Inventory (V) \\
\hline $\begin{array}{l}\text { Shipping Finished } \\
\text { Products }\end{array}$ & All shipments are recorded. & Inventory (V), Cost of Sales (V) \\
\hline $\begin{array}{l}\text { Shipping Finished } \\
\text { Products }\end{array}$ & Shipments are recorded accurately. & Inventory (R), Cost of Sales (R) \\
\hline $\begin{array}{l}\text { Shipping Finished } \\
\text { Products }\end{array}$ & Shipments are recorded in a timely manner and in the appropriate period. & Inventory $(\mathrm{Cu})$, Cost of Sales $(\mathrm{Cu})$ \\
\hline $\begin{array}{l}\text { Shipping Finished } \\
\text { Products }\end{array}$ & $\begin{array}{l}\text { Inventory is released only when goods are shipped with approved } \\
\text { customer orders. }\end{array}$ & Inventory (Co), Cost of Sales (Co) \\
\hline $\begin{array}{c}\text { Maintaining } \\
\text { Inventory Master File }\end{array}$ & Only valid changes are made to the inventory management master file. & Inventory $(\mathrm{V}, \mathrm{Co})$, Cost of Sales $(\mathrm{V}, \mathrm{Co})$ \\
\hline $\begin{array}{l}\text { Maintaining Inventory } \\
\text { Master File }\end{array}$ & $\begin{array}{l}\text { All valid changes to the inventory management master file are input and } \\
\text { processed. }\end{array}$ & Inventory (V, Co), Cost of Sales (V, Co) \\
\hline $\begin{array}{l}\text { Maintaining Inventory } \\
\text { Master File }\end{array}$ & Changes to the inventory management master file are accurate. & Inventory (R), Cost of Sales (R) \\
\hline $\begin{array}{l}\text { Maintaining Inventory } \\
\text { Master File }\end{array}$ & Changes to the inventory management master file are processed timely. & Inventory $(\mathrm{V}, \mathrm{Co})$, Cost of Sales $(\mathrm{V}, \mathrm{Co})$ \\
\hline $\begin{array}{l}\text { Maintaining Inventory } \\
\text { Master File }\end{array}$ & Inventory management master file remains pertinent. & Inventory $(\mathrm{Co}, \mathrm{V})$, Cost of Sales $(\mathrm{Co}, \mathrm{V})$ \\
\hline
\end{tabular}

*Assertion abbreviations: $\mathbf{C o}=$ Completeness; $\mathbf{C u}=$ Cutoff $\mathbf{P}=$ Presentation; $\mathbf{R}=$ Recording; $\mathbf{V}=$ Validity; $\mathbf{\$}=$ Valuation. 
Exhibit 4: Control Objectives Reconciliation for the Payroll and Personnel Cycle

\begin{tabular}{|c|c|c|}
\hline $\begin{array}{l}\text { Principal } \\
\text { Business } \\
\text { Activity } \\
\end{array}$ & Control Objective & $\begin{array}{l}\text { Accounts Affected (Auditor Assertion Addressed by that } \\
\text { Control Objective*) }\end{array}$ \\
\hline Hiring Personnel & Additions to the payroll master file represent valid employees. & $\begin{array}{l}\text { Payroll }(\mathrm{V}) \\
\text { Accrued Expenses (V) }\end{array}$ \\
\hline Hiring Personnel & All new employees are added to the payroll master file. & $\begin{array}{l}\text { Payroll (Co) } \\
\text { Accrued Expenses (Co) }\end{array}$ \\
\hline Terminating Personnel & Terminated employees are removed from the payroll master file. & $\begin{array}{l}\text { Payroll (V) } \\
\text { Accrued Expenses (V) }\end{array}$ \\
\hline Terminating Personnel & Employees are only terminated within statutory and union requirements. & $\begin{array}{l}\text { Payroll (Co) } \\
\text { Accrued Expenses (Co) }\end{array}$ \\
\hline Terminating Personnel & Deletions from the payroll master file represent valid terminations. & $\begin{array}{l}\text { Payroll (Co) } \\
\text { Accrued Expenses (Co) }\end{array}$ \\
\hline Recording Time & $\begin{array}{l}\text { Time and attendance data recorded reflects actual time worked and is } \\
\text { authorized. }\end{array}$ & $\begin{array}{l}\text { Payroll (V) } \\
\text { Accrued Expenses (V) }\end{array}$ \\
\hline Recording Time & All time worked is input. & $\begin{array}{l}\text { Payroll (Co) } \\
\text { Accrued Expenses (Co) }\end{array}$ \\
\hline Recording Time & Time worked is accurately input and processed. & $\begin{array}{l}\text { Payroll (R) } \\
\text { Accrued Expenses (R) }\end{array}$ \\
\hline Recording Time & Time worked is processed in a timely manner. & $\begin{array}{l}\text { Payroll }(\mathrm{Cu}) \\
\text { Accrued Expenses }(\mathrm{Cu})\end{array}$ \\
\hline Calculating Payroll & Payroll is recorded in the appropriate period. & $\begin{array}{l}\text { Payroll }(\mathrm{Cu}) \\
\text { Accrued Expenses }(\mathrm{Cu})\end{array}$ \\
\hline Calculating Payroll & $\begin{array}{l}\text { Payroll (including compensation and withholdings) is accurately calculated and } \\
\text { recorded. }\end{array}$ & $\begin{array}{l}\text { Payroll (R) } \\
\text { Accrued Expenses (R) }\end{array}$ \\
\hline Calculating Payroll & $\begin{array}{l}\text { Payroll related accruals/provisions reflect the existing business circumstances } \\
\text { and economic conditions in accordance with the accounting policies being used. }\end{array}$ & Accrued Expenses $(\$)$ \\
\hline Calculating Payroll & $\begin{array}{l}\text { Financial information is not presented in a misleading way, and all information } \\
\text { that is necessary for fair presentation and compliance with professional } \\
\text { standards or legal requirements is disclosed. }\end{array}$ & $\begin{array}{l}\text { Payroll }(\mathrm{P}) \\
\text { Accrued Expenses }(\mathrm{P})\end{array}$ \\
\hline Disbursing Payroll & $\begin{array}{l}\text { Payroll disbursements and recorded payroll expenses relate to actual time } \\
\text { worked. }\end{array}$ & $\begin{array}{l}\text { Payroll }(\mathrm{V}) \\
\text { Accrued Expenses (V) }\end{array}$ \\
\hline
\end{tabular}

*Assertion abbreviations: $\mathbf{C o}=$ Completeness; $\mathbf{C u}=$ Cutoff; $\mathbf{P}=$ Presentation; $\mathbf{R}=$ Recording; $\mathbf{V}=$ Validity; $\$=$ Valuation. 
Exhibit 4: Control Objectives Reconciliation for the Payroll and Personnel Cycle (continued)

\begin{tabular}{|c|c|c|}
\hline $\begin{array}{l}\text { Principal } \\
\text { Business } \\
\text { Activity }\end{array}$ & Control Objective & $\begin{array}{l}\text { Accounts Affected (Auditor Assertion Addressed by that } \\
\text { Control Objective*) }\end{array}$ \\
\hline Disbursing Payroll & Payroll is disbursed to appropriate employees. & $\begin{array}{l}\text { Payroll (V) } \\
\text { Accrued Expenses (V) }\end{array}$ \\
\hline $\begin{array}{l}\text { Maintaining Payroll Master } \\
\text { Files }\end{array}$ & Only valid changes are made to the payroll master files. & $\begin{array}{l}\text { Payroll }(\mathrm{V}, \mathrm{Co}) \\
\text { Accrued Expenses }(\mathrm{V}, \mathrm{Co})\end{array}$ \\
\hline $\begin{array}{c}\text { Maintaining Payroll Master } \\
\text { Files }\end{array}$ & All valid changes to the payroll master files are input and processed. & $\begin{array}{l}\text { Payroll }(\mathrm{V}, \mathrm{Co}) \\
\text { Accrued Expenses }(\mathrm{V}, \mathrm{Co})\end{array}$ \\
\hline $\begin{array}{c}\text { Maintaining Payroll Master } \\
\text { Files }\end{array}$ & Changes to the payroll master files are accurate. & $\begin{array}{l}\text { Payroll (R) } \\
\text { Accrued Expenses (R) }\end{array}$ \\
\hline $\begin{array}{c}\text { Maintaining Payroll Master } \\
\text { Files }\end{array}$ & Changes to the payroll master files are processed in a timely manner. & $\begin{array}{l}\text { Payroll }(\mathrm{V}, \mathrm{Co}) \\
\text { Accrued Expenses }(\mathrm{V}, \mathrm{Co})\end{array}$ \\
\hline $\begin{array}{c}\text { Maintaining Payroll Master } \\
\text { Files }\end{array}$ & Payroll master files data remains pertinent. & $\begin{array}{l}\text { Payroll }(\mathrm{Co}, \mathrm{V}) \\
\text { Accrued Expenses }(\mathrm{Co}, \mathrm{V})\end{array}$ \\
\hline $\begin{array}{c}\text { Maintaining Payroll Master } \\
\text { Files } \\
\end{array}$ & Only valid changes are made to the payroll withholding tables. & Accrued Expenses (V, Co) \\
\hline $\begin{array}{c}\text { Maintaining Payroll Master } \\
\text { Files }\end{array}$ & All valid changes to the payroll withholding tables are input and processed. & Accrued Expenses (V, Co) \\
\hline $\begin{array}{c}\text { Maintaining Payroll Master } \\
\text { Files }\end{array}$ & Changes to the payroll withholding tables are accurate. & Accrued Expenses (R) \\
\hline $\begin{array}{c}\text { Maintaining Payroll Master } \\
\text { Files }\end{array}$ & Changes to the payroll withholding tables are processed in a timely manner. & Accrued Expenses (V, Co) \\
\hline $\begin{array}{c}\text { Maintaining Payroll Master } \\
\text { Files }\end{array}$ & Payroll withholding table data remains pertinent. & Accrued Expenses $(\mathrm{Co}, \mathrm{V})$ \\
\hline $\begin{array}{c}\text { Maintaining Payroll Master } \\
\text { Files }\end{array}$ & Statutory withholding tables are consistent with statutory requirements. & Accrued Expenses $(\mathrm{Co}, \mathrm{V})$ \\
\hline
\end{tabular}

*Assertion abbreviations: $\mathbf{C o}=$ Completeness; $\mathbf{C u}=$ Cutoff; $\mathbf{P}=$ Presentation; $\mathbf{R}=$ Recording; $\mathbf{V}=$ Validity; $\$=$ Valuation. 
Exhibit 5: Control Objectives Reconciliation for the Billings Cycle

\begin{tabular}{|c|c|c|}
\hline $\begin{array}{l}\text { Principal } \\
\text { Business } \\
\text { Activity }\end{array}$ & Control Objective & $\begin{array}{c}\text { Accounts Affected (Auditor } \\
\text { Assertion Addressed by that Contro } \\
\text { Objective*) }\end{array}$ \\
\hline $\begin{array}{l}\text { Managing and Processing } \\
\text { Billings }\end{array}$ & Billings are approved by project managers as to contract specifications. & Receivables (V) \\
\hline $\begin{array}{l}\text { Managing and Processing } \\
\text { Billings }\end{array}$ & Billings and cancellations of billings are input accurately. & Receivables (R) \\
\hline Invoicing & Billings are accurately calculated and recorded. & Receivables (R) \\
\hline Invoicing & Adjustments to accounts receivable are accurately calculated and recorded. & Receivables (R) \\
\hline Invoicing & All billings processed are recorded. & Receivables (Co) \\
\hline Invoicing & Billings are recorded in the appropriate period. & Receivables $(\mathrm{Cu})$ \\
\hline Invoicing & $\begin{array}{l}\text { Accounts Receivable reflect the existing business circumstances and economic conditions in } \\
\text { accordance with the accounting policies being used. }\end{array}$ & Receivables $(\$)$ \\
\hline Invoicing & $\begin{array}{l}\text { Accounts Receivable information is not presented in a misleading way and all information that is } \\
\text { necessary for fair presentation and compliance with professional standards or legal requirements is } \\
\text { disclosed. }\end{array}$ & Receivables (P) \\
\hline Processing Cash Receipts & Cash receipts are recorded in the period in which they are received. & Receivables $(\mathrm{Cu})$ \\
\hline Processing Cash Receipts & Cash receipts data is entered for processing accurately. & Receivables (R) \\
\hline Processing Cash Receipts & All cash receipts data is entered for processing. & Receivables (V) \\
\hline Processing Cash Receipts & Cash receipts data is valid and is entered for processing only once. & Receivables (Co) \\
\hline Processing Cash Receipts & Timely collection of accounts receivable is monitored. & Receivables (\$) \\
\hline $\begin{array}{l}\text { Maintaining Contract } \\
\text { Master File }\end{array}$ & Only valid changes are made to the contract master file. & Receivables $(\mathrm{Co}, \mathrm{V})$ \\
\hline $\begin{array}{l}\text { Maintaining Contract Master } \\
\text { File }\end{array}$ & All valid changes to the contract master file are input and processed. & Receivables $(\mathrm{Co}, \mathrm{V})$ \\
\hline $\begin{array}{l}\text { Maintaining Contract Master } \\
\text { File }\end{array}$ & Changes to the contract master file are accurate. & Receivables (R) \\
\hline $\begin{array}{l}\text { Maintaining Contract Master } \\
\text { File }\end{array}$ & Changes to the contract master file are processed in a timely manner. & Receivables $(\mathrm{Co}, \mathrm{V})$ \\
\hline
\end{tabular}

*Assertion abbreviations: Co = Completeness; $\mathbf{C u}=$ Cutoff; $\mathbf{P}=$ Presentation; $\mathbf{R}=$ Recording; $\mathbf{V}=$ Validity; $\$=$ Valuation. 
Exhibit 6: Control Objectives Reconciliation for the Treasury Cycle

\begin{tabular}{|c|c|c|}
\hline $\begin{array}{c}\text { Principal } \\
\text { Business } \\
\text { Activity }\end{array}$ & Control Objective & $\begin{array}{l}\text { Accounts Affected (Auditor Assertion Addressed by that } \\
\text { Control Objective*) }\end{array}$ \\
\hline Borrowing & Recorded debt represents a valid liability of the organization. & Notes Payable \& Long-Term Debt (V) \\
\hline Borrowing & Borrowings are recorded accurately as to amounts and terms. & Notes Payable \& Long-Term Debt (R) \\
\hline Borrowing & All borrowings are recorded. & Notes Payable \& Long-Term Debt (Co) \\
\hline Borrowing & Borrowings are recorded in the appropriate period. & Notes Payable \& Long-Term Debt $(\mathrm{Cu})$ \\
\hline Borrowing & All interest is accurately calculated and recorded in the appropriate period. & $\begin{array}{l}\text { Investment Income and } \\
\text { Interest Expense }(\mathrm{Co}, \mathrm{V}, \mathrm{R}, \mathrm{Cu})\end{array}$ \\
\hline Borrowing & Recorded loan repayments are valid. & Notes Payable \& Long-Term Debt (Co) \\
\hline Borrowing & Loan repayments are accurately recorded. & Notes Payable \& Long-Term Debt (R) \\
\hline Borrowing & All loan repayments are recorded. & Notes Payable \& Long-Term Debt (V) \\
\hline Borrowing & Loan repayments are recorded in the appropriate period. & Notes Payable \& Long-Term Debt $(\mathrm{Cu})$ \\
\hline Borrowing & Loans are repaid in accordance with the terms of the loan. & Notes Payable \& Long-Term Debt (Co) \\
\hline Borrowing & The organization complies with loan covenants. & Notes Payable \& Long-Term Debt (Co) \\
\hline $\begin{array}{l}\text { Managing Cash And } \\
\text { Investments }\end{array}$ & Recorded investments represent assets of the organization. & Investments/Derivatives (V) \\
\hline $\begin{array}{l}\text { Managing Cash And } \\
\text { Investments }\end{array}$ & Investment purchases, sales, and maturities are accurately recorded. & Investments/Derivatives (R) \\
\hline $\begin{array}{l}\text { Managing Cash And } \\
\text { Investments }\end{array}$ & All investment transactions are recorded. & Investments/Derivatives (Co) \\
\hline $\begin{array}{l}\text { Managing Cash And } \\
\text { Investments }\end{array}$ & Investment transactions are recorded in the appropriate period. & Investments/Derivatives $(\mathrm{Cu})$ \\
\hline $\begin{array}{l}\text { Managing Cash And } \\
\text { Investments }\end{array}$ & $\begin{array}{l}\text { All investment income is accurately calculated and recorded in the } \\
\text { appropriate period. }\end{array}$ & $\begin{array}{l}\text { Investment Income and } \\
\text { Interest Expense }(\mathrm{Co}, \mathrm{V}, \mathrm{R}, \mathrm{Cu})\end{array}$ \\
\hline $\begin{array}{l}\text { Managing Cash And } \\
\text { Investments }\end{array}$ & $\begin{array}{l}\text { Loans and investments reflect the existing business circumstances and } \\
\text { economic conditions in accordance with the accounting policies being used. }\end{array}$ & $\begin{array}{l}\text { Notes Payable \& Long-Term Debt (\$), } \\
\text { Investments/Derivatives (\$) }\end{array}$ \\
\hline
\end{tabular}

*Assertion abbreviations: $\mathbf{C o}=$ Completeness; $\mathbf{C u}=$ Cutoff; $\mathbf{P}=$ Presentation; $\mathbf{R}=$ Recording; $\mathbf{V}=$ Validity $; \mathbf{\$}=$ Valuation. 


\section{Exhibit 6: Control Objectives Reconciliation for the Treasury Cycle (continued)}

\begin{tabular}{|c|c|c|}
\hline $\begin{array}{c}\text { Principal } \\
\text { Business } \\
\text { Activity } \\
\end{array}$ & Control Objective & $\begin{array}{l}\text { Accounts Affected (Auditor Assertion Addressed by that } \\
\text { Control Objective*) }\end{array}$ \\
\hline $\begin{array}{l}\text { Managing Cash And } \\
\text { Investments }\end{array}$ & $\begin{array}{l}\text { Financial information is appropriately presented and all information that is } \\
\text { necessary for fair presentation and compliance with professional standards or } \\
\text { legal requirements is disclosed. }\end{array}$ & $\begin{array}{l}\text { Notes Payable \& Long-Term Debt }(\mathrm{P}) \\
\text { Investments/Derivatives }(\mathrm{P}) \text {, } \\
\text { Investment Income and Interest Expense }(\mathrm{P})\end{array}$ \\
\hline $\begin{array}{l}\text { Managing Derivative } \\
\text { Transactions }\end{array}$ & $\begin{array}{l}\text { Senior management has an understanding of the organization's derivative } \\
\text { activities. }\end{array}$ & $\begin{array}{l}\text { Investments/Derivatives }(\mathrm{V}, \mathrm{Co}, \mathrm{R}, \mathrm{Cu}, \mathrm{P}) \text {, } \\
\text { Off-Balance-Sheet Derivative Transactions }(\mathrm{P}) \\
\text { Investment Income and } \\
\text { Interest Expense }(\mathrm{V}, \mathrm{Co}, \mathrm{R}, \mathrm{Cu})\end{array}$ \\
\hline $\begin{array}{c}\text { Managing Derivative } \\
\text { Transactions } \\
\end{array}$ & $\begin{array}{l}\text { Recorded derivative transactions represent assets or liabilities of the } \\
\text { organization. }\end{array}$ & Investments/Derivatives (V) \\
\hline $\begin{array}{l}\text { Managing Derivative } \\
\text { Transactions }\end{array}$ & $\begin{array}{l}\begin{array}{l}\text { Disclosed off-balance sheet derivative } \\
\text { transactions. }\end{array} \\
\end{array}$ & Off-Balance-Sheet Derivative Transactions (P) \\
\hline $\begin{array}{c}\text { Managing Derivative } \\
\text { Transactions }\end{array}$ & Derivative transactions are accurately recorded. & Investments/Derivatives (R) \\
\hline $\begin{array}{l}\text { Managing Derivative } \\
\text { Transactions }\end{array}$ & Disclosed off-balance sheet derivative transactions are properly presented. & Off-Balance-Sheet Derivative Transactions (P) \\
\hline $\begin{array}{l}\text { Managing Derivative } \\
\text { Transactions }\end{array}$ & All derivative transactions are recorded in the financial statements. & Investments/Derivatives (Co) \\
\hline $\begin{array}{c}\text { Managing Derivative } \\
\text { Transactions }\end{array}$ & $\begin{array}{l}\text { All off-balance sheet derivative transactions are disclosed in the financial } \\
\text { statements. }\end{array}$ & Off-Balance-Sheet Derivative Transactions (P) \\
\hline $\begin{array}{l}\text { Managing Derivative } \\
\text { Transactions }\end{array}$ & Derivative transactions are recorded in the appropriate period. & Investments/Derivatives $(\mathrm{Cu})$ \\
\hline $\begin{array}{l}\text { Managing Derivative } \\
\text { Transactions }\end{array}$ & $\begin{array}{l}\text { Off-balance sheet derivative transactions are recorded in the financial } \\
\text { statements in the appropriate period. }\end{array}$ & Off-Balance-Sheet Derivative Transactions (P) \\
\hline $\begin{array}{l}\text { Managing Derivative } \\
\text { Transactions } \\
\end{array}$ & $\begin{array}{l}\text { All investment income on derivative transactions is accurately calculated and } \\
\text { recorded in the appropriate period. }\end{array}$ & $\begin{array}{l}\text { Investment Income and } \\
\text { Interest Expense }(\mathrm{V}, \mathrm{Co}, \mathrm{R}, \mathrm{Cu})\end{array}$ \\
\hline $\begin{array}{l}\text { Managing Derivative } \\
\text { Transactions }\end{array}$ & $\begin{array}{l}\text { All interest expense on derivative transactions is accurately calculated and } \\
\text { recorded in the appropriate period. }\end{array}$ & $\begin{array}{l}\text { Investment Income and } \\
\text { Interest Expense }(\mathrm{V}, \mathrm{Co}, \mathrm{R}, \mathrm{Cu})\end{array}$ \\
\hline $\begin{array}{l}\text { Managing Derivative } \\
\text { Transactions } \\
\end{array}$ & $\begin{array}{l}\text { Derivative transactions reflect the existing business circumstances and } \\
\text { economic conditions in accordance with the accounting policies being used. }\end{array}$ & $\begin{array}{l}\text { Investments/Derivatives (\$) } \\
\text { Off-Balance-Sheet Derivative Transactions (P) }\end{array}$ \\
\hline
\end{tabular}

*Assertion abbreviations: $\mathbf{C o}=$ Completeness; $\mathbf{C u}=$ Cutoff; $\mathbf{P}=$ Presentation $\mathbf{R}=$ Recording; $\mathbf{V}=$ Validity; $\$=$ Valuation. 
Exhibit 7: Control Objectives Reconciliation for the Estimating, Job Cost, And Revenue Recognition Cycle

\begin{tabular}{|c|c|c|}
\hline $\begin{array}{l}\text { Principal } \\
\text { Business } \\
\text { Activity }\end{array}$ & Control Objective & $\begin{array}{c}\text { Accounts Affected (Auditor Assertion Addressed by that Control } \\
\text { Objective*) }\end{array}$ \\
\hline $\begin{array}{l}\text { Estimating And } \\
\text { Bidding }\end{array}$ & $\begin{array}{l}\text { Contract job bids are prepared with reliable estimates prior to } \\
\text { submission. }\end{array}$ & $\begin{array}{l}\text { Job Costs (V, Co), Revenue (V, Co), } \\
\text { Over/Under Billings (V, Co) }\end{array}$ \\
\hline $\begin{array}{l}\text { Estimating And } \\
\text { Bidding }\end{array}$ & Estimate revisions are accurate and timely. & $\begin{array}{l}\text { Revenue }(\mathrm{Co}, \mathrm{Cu}, \mathrm{R}) \\
\text { Over/Under Billings }(\mathrm{Co}, \mathrm{Cu}, \mathrm{R})\end{array}$ \\
\hline Job Costing & Payroll expenses are coded to the proper job and cost category. & $\begin{array}{l}\text { Job Costs }(\mathrm{R}, \mathrm{Co}), \text { Revenue }(\mathrm{R}, \mathrm{Co}) \text {, } \\
\text { Over/Under Billings }(\mathrm{R}, \mathrm{Co})\end{array}$ \\
\hline Job Costing & $\begin{array}{l}\text { Purchases/subcontract costs are coded to the proper job and cost } \\
\text { category. }\end{array}$ & $\begin{array}{l}\text { Job Costs }(\mathrm{R}, \mathrm{Co}), \text { Revenue }(\mathrm{R}, \mathrm{Co}), \\
\text { Over/Under Billings }(\mathrm{R}, \mathrm{Co})\end{array}$ \\
\hline Job Costing & $\begin{array}{l}\text { Job cost adjustments and revisions (i.e. credits, transfers, other } \\
\text { maintenance) are recorded to the proper job and cost categories. }\end{array}$ & $\begin{array}{l}\text { Job Costs }(\mathrm{R}, \mathrm{V}), \text { Revenue }(\mathrm{R}, \mathrm{V}) \\
\text { Over/Under Billings }(\mathrm{R}, \mathrm{V})\end{array}$ \\
\hline Job Costing & Job cost reports are mathematically accurate. & $\begin{array}{l}\text { Job Costs (R), Revenue (R), } \\
\text { Over/Under Billings }(\mathrm{R})\end{array}$ \\
\hline Job Costing & Job cost system agrees to general ledger. & $\begin{array}{l}\text { Job Costs }(\mathrm{R}), \text { Revenue }(\mathrm{R}) \text {, } \\
\text { Over/Under Billings }(\mathrm{R})\end{array}$ \\
\hline $\begin{array}{c}\text { Revenue } \\
\text { Recognition }\end{array}$ & $\begin{array}{l}\text { Contract values, including change orders, are recorded accurately } \\
\text { and in a timely manner. }\end{array}$ & $\begin{array}{l}\text { Revenue }(\mathrm{Co}, \mathrm{Cu}) \\
\text { Over/Under Billings }(\mathrm{Co}, \mathrm{Cu})\end{array}$ \\
\hline Revenue Recognition & Percentage of completion is calculated accurately. & $\begin{array}{l}\text { Revenue (R), } \\
\text { Over/Under Billings (R) }\end{array}$ \\
\hline Revenue Recognition & Revenue recognized is calculated accurately. & $\begin{array}{l}\text { Revenue (R), } \\
\text { Over/Under Billings (R) }\end{array}$ \\
\hline Revenue Recognition & $\begin{array}{l}\text { High level revisions of revenue recognition are accurate and } \\
\text { appropriate. }\end{array}$ & $\begin{array}{l}\text { Revenue (V, R), } \\
\text { Over/Under Billings (V, R) }\end{array}$ \\
\hline Revenue Recognition & Progress billings are coded to the proper job & Over/Under Billings (R) \\
\hline Revenue Recognition & Over/under billings are calculated accurately. & Over/Under Billings $(\mathrm{R})$ \\
\hline
\end{tabular}

*Assertion abbreviations: $\mathbf{C o}=$ Completeness; $\mathbf{C u}=$ Cutoff; $\mathbf{P}=$ Presentation $\mathbf{R}=$ Recording; $\mathbf{V}=$ Validity; $\$=$ Valuation. 


\section{SUMMARY AND CONCLUSION}

This paper presents a tool that is potentially useful to independent auditors performing a preliminary assessment of the design of the internal control system of a client in the construction industry. This tool, the Control Objectives Reconciliation, is important and timely because of both current economic conditions and recent changes in PCAOB auditing standards. A comparison by the auditor of the control objectives of the client's system with those shown in Exhibits 1-7 will help ensure that no important control objectives have been omitted from the client's system - and in cases of omission, will serve to remind the auditor to consider the effect of the omission on his or her preliminary assessment of the client's control system. Construction company CFOs and controllers who have concerns about the adequacy of their company's internal control system will find Exhibits 1-7 to be practical benchmark for comparison.

\section{ACKNOWLEDGMENT}

The authors wish to thank the management of a large CPA firm, which has requested anonymity, for allowing access to documents which were useful in the preparation of this paper.

\section{AUTHOR BIOGRAPHIES}

Lou X. Orchard is an Assistant Professor at Clayton State University, Morrow, Georgia. He received his B.A. degree in Business Administration (Accounting) and his MBA from the University of Washington, and his Ph.D. in Business Administration (Accounting) from the University of Arizona. In addition to these schools, Dr. Orchard has also taught accounting at the University of Houston (where he taught Auditing and Advanced Auditing) and Wichita State University. He has worked for what is now a Big Four CPA firm, as well as a commercial real estate company.

Scott L. Butterfield is an Associate Professor of Accounting at Clayton State University, Morrow, Georgia. Dr. Butterfield worked as a tax consultant for Coopers \& Lybrand, performing consulting and compliance work for a variety of clients in varied industries, including: Banking, Manufacturing, Restaurant/Food Services, Biotech, Electric Co-Generation, and Non-Profit, as well as for high-net-worth individuals. His research interests include: Taxpayer Behavior, Taxes and Public Policy, Managerial and Cost Accounting.

\section{REFERENCES}

1. American Institute of Certified Public Accountants (AICPA) auditing standards (AU) Section 326, http://www.aicpa.org/download/members/div/auditstd/AU-00326.PDF

2. Public Company Accounting Oversight Board (2004), Auditing Standard No. 2, "An Audit of Internal Control Over Financial Reporting Performed in Conjunction With An Audit of Financial Statements," http://www.pcaobus.org/Standards/Standards_and_Related_Rules/Auditing_Standard_No.2.aspx.

3. Public Company Accounting Oversight Board (2007), Auditing Standard No. 5, "An Audit of Internal Control Over Financial Reporting That Is Integrated with An Audit of Financial Statements," http://www.pcaobus.org/Standards/Standards_and_Related_Rules/Auditing_Standard_No.5.aspx 
NOTES 